IF Sér. Reg. n. 55 p. 5-27 dez. 2017

http://dx.doi.org/10.4322/ifsr.2018.001

ISSN on-line 2179-2372

\title{
REPRESA GUARAPIRANGA: CONFLITOS ENTRE DIREITO À MORADIA E DIREITO A UM MEIO AMBIENTE ECOLOGICAMENTE EQUILIBRADO ${ }^{1}$
}

\section{GUARAPIRANGA DAM: CONFLICTS BETWEEN THE RIGHT TO DWELLING AND THE RIGHT TO AN ECOLOGICALLY BALANCED ENVIRONMENT}

\author{
Augusto Rapp de Eston Pinto COELHO ${ }^{2}$
}

RESUMO - O presente trabalho teve por objetivo estudar a ocupação da região que margeia a Represa Guarapiranga, localizada na região sul da Região Metropolitana de São Paulo. Foram observados os aspectos históricos da ocupação humana nesta região, verificando-se ainda o avanço da legislação que incide na região. A competência de cada ente legislativo na construção do ordenamento jurídico incidente e as suas repercussões nas demais leis foram apontadas. Nesse sentido, é de se observar o conflito constituído em relação ao Direito Urbanístico, em especial do Direito à Moradia, em face do Direito a um Meio Ambiente ecologicamente equilibrado. Por fim foi feita uma análise dos avanços ocorridos tanto em termos do Direito Urbanístico quanto em relação ao Meio Ambiente na região.

Palavras-chave: ocupação de represa; mananciais de água; legislação ambiental; Direito Urbanístico.

\begin{abstract}
The objective of this work was to study the occupation of the region that borders the Guarapiranga Reservoir, located in the southern region of Greater São Paulo. The historical aspects of human occupation were observed in this region, still checking up advancing legislation that focuses on the region. The jurisdiction of each legislative entity in the construction of the legal system incident and its repercussions on other laws were pointed out. In this sense, it is to observe the conflict made in relation to the planning law, especially the right to housing, given the right to an ecologically balanced environment. Finally, an analysis was made of the progress made both in terms of urban law and in relation to the environment in the region.
\end{abstract}

Keywords: dam occupation; water sources; environmental legislation; Urban Planning Law. 


\section{INTRODUÇÃO}

O biênio 2014/2015 ficou marcado devido à grave crise hídrica que a região metropolitana de São Paulo vivenciou, sendo considerada a pior crise registrada desde 1930, ano em que foram iniciadas as medições nos sistemas de reservatórios que abasteciam a cidade. Este período foi marcado pela diminuição de forma contínua da precipitação das chuvas nas cabeceiras dos rios que constituem os mananciais da região. Essa queda no volume das chuvas fez com que o principal sistema de abastecimento da região (Sistema Cantareira) passasse a operar utilizando para abastecimento a água da considerada reserva técnica, ou seja, a água disponível para abastecimento estava localizada em nível inferior ao das bombas de captação (Companhia de Saneamento Básico do Estado de São Paulo - SABESP, 2015).

Tal situação ensejou a limitação de captação de água do principal sistema da Grande São Paulo para abastecer a população, obrigando a SABESP, em conjunto com o Governo do Estado de São Paulo, a buscar alternativas para suprir, bem como reduzir, a captação de águas do Sistema Cantareira. Uma das alternativas encontradas pela SABESP foi aumentar a captação de água dos demais mananciais da região e, em especial, dos sistemas Billings e Guarapiranga.

Ambos os sistemas se encontram encravados na região sul da cidade de São Paulo, apresentando como semelhança a proximidade da ocupação urbana de suas bordas, ocasionando, em virtude desta proximidade, um conflito entre o meio ambiente dos mananciais e o próprio homem.

O presente estudo teve como objetivo promover uma reflexão quanto à ocupação das bordas das represas e apresentar, de modo breve, princípios e direitos presentes neste conflito entre o meio ambiente e a ocupação do homem. Objetivou-se ainda um estudo profundo quanto a ocupação das bordas da Represa Guarapiranga, partindo desde a sua inauguração até os tempos atuais, expondo assim este conflito a luz dos princípios constitucionais, bem como do Direito Administrativo, do Direito Urbanístico e do Direito Ambiental.

\section{MATERIAL E MÉTODOS}

A Represa Guarapiranga é formada pelos rios Embu-Mirim, Embu-Guaçu, Santa Rita, Vermelho, Ribeirão Itaim, Capivari e Parelheiros e abrange parcelas territoriais dos municípios de Itapecerica da Serra, Embu-Guaçu e São Paulo, com um espelho d'água de 26,6 km² e um perímetro de $85 \mathrm{~km}$. Junto com a Represa Billings, constitui o Sistema Guarapiranga, que é o segundo maior sistema de água da Região Metropolitana de São Paulo, produzindo 15 mil litros de água por segundo e abastecendo 4,9 milhões de pessoas das Zonas Sul e Sudoeste da Capital (São Paulo, 2016a).

Realizou-se o estudo em 2016 da ocupação da região que margeia a Represa Guarapiranga através da observação dos aspectos históricos da ocupação humana desde a construção da represa até os tempos atuais, utilizando para tanto publicações em meios de comunicação como jornais, bem como o Relatório Final do projeto denominado Atualização do Plano de Desenvolvimento e Proteção Ambiental da Bacia Hidrográfica do Guarapiranga elaborado em 2006, pela Companhia Brasileira de Projetos e Empreendimentos em conjunto com a Coordenadoria de Planejamento Ambiental Estratégico e Educação Ambiental da Secretaria do Meio Ambiente.

Verificou-se o avanço da legislação que incide na região, a competência de cada ente legislativo na construção do ordenamento jurídico incidente e as suas repercussões nas demais leis e também uma análise dos avanços ocorridos tanto em termos do Direito Urbanístico, quanto em relação ao Meio Ambiente na região, partindo desde a Constituição Federal até a legislação municipal vigente.

Realizou-se a análise de algumas medidas adotadas recentemente pelos entes municipais e estaduais para a recuperação do manancial e a conexão entre os princípios e direitos expostos, e demonstrada a necessidade de aplicação deles no que tange a ocupação das bordas das represas em termos genéricos e em especial da Represa Guarapiranga. 


\section{RESULTADOS E DISCUSSÃO}

\subsection{DOS DIREITOS E PRINCÍPIOS RELACIONADOS}

\subsubsection{Do Direito Ambiental}

O legislador constitucional brasileiro estabeleceu no Art. 225 da Constituição Federal (Brasil, 1988) o norte para a proteção ao Meio Ambiente no Brasil, expondo para tanto os princípios e as diretrizes a serem visadas e almejadas tanto pelo Poder Público no exercício das suas funções executiva e legislativa, bem como pela própria população. Neste sentido, destaca-se o "caput" do Art. 225, o qual estabelece que é um direito individual a garantia de um meio ambiente ecologicamente equilibrado, tratando-se assim de um bem de uso comum e essencial à sadia qualidade de vida.

\subsubsection{Do Meio Ambiente ecologicamente equilibrado}

O direito ao meio ambiente ecologicamente equilibrado é fixado no caput do Art. 225 da Constituição Federal (Brasil, 1988) como um primado a ser buscado e exigido no ordenamento jurídico brasileiro.

Na visão de Édis Milaré, em seu livro Direito do Ambiente, esse direito compreende "como uma extensão do direito à vida, quer sob o enfoque da própria existência física e saúde dos seres humanos, quer quanto ao aspecto da dignidade dessa existência - a qualidade de vida", assim e caso não seja entendido como um direito fundamental, deverá ser entendido como um dos elementos formadores dos direitos e garantias fundamentais, em especial do direito à vida. Observou ainda Édis Milaré que, no seu entendimento, o direito ao meio ambiente ecologicamente equilibrado, embora esteja no artigo 225, pode ser entendido como inserido no rol dos direitos e deveres individuais previstos no artigo $5^{\circ}$ da Carta Magna. E para tanto seguiu a tradição do constitucionalismo brasileiro admitindo assim a existência de "outros direitos decorrentes do regime e dos princípios por ela adotados, ou dos tratados internacionais em que a República Federativa do Brasil seja parte" (Milaré, 2015, p.258, p.259).

Do ponto de vista ecológico, conforme Paulo Affonso Leme Machado, "consubstancia-se na conservação das propriedades e das funções naturais desse meio, de forma a permitir a existência, a evolução e o desenvolvimento dos seres vivos" (Machado, 2016, p.56). Observa-se, porém, que esse equilíbrio não corresponde a uma não intervenção humana no meio ambiente, mas sim que essa intervenção ocorra de modo que não desequilibre significativamente este ambiente.

Ressalta-se que o conceito de equilíbrio é algo relativo, uma vez que o próprio meio ambiente, seja ele natural ou artificial, está em constante modificação e/ou evolução, seja por influência de modificações climáticas naturais (quantidade de chuvas, fenômenos do "El Niño" e "La Niña", etc.), seja por influência de modificações ocasionadas pelo homem.

Na própria Constituição Federal, no Art. 225 (Brasil, 1988), o constituinte originário estabeleceu incumbências ao Poder Público, ou seja, estabeleceu incumbências a todos os entes da federação, para que estes promovam a garantia a um meio ambiente equilibrado. Em especial, essa atuação do Poder Público se daria através da preservação e restauração dos processos ecológicos essenciais e de prover o manejo ecológico das espécies e ecossistemas com a tentativa de preservá-los o máximo possível. 


\subsubsection{Da obrigatoriedade de intervenção do Poder Público}

A Constituição Federal, no $\S 1^{\circ}$ do Art. 225, (Brasil, 1988) confere ao Poder Público a incumbência de intervir na gestão do meio ambiente, apresentando em seus incisos diversas atribuições que deverão ser observadas e respeitadas tanto no que tange a elaboração do ordenamento jurídico infraconstitucional, bem como na elaboração de políticas públicas voltadas a gestão do meio ambiente e na fiscalização das intervenções realizadas nesses espaços.

Essa atribuição constitucional vem em consonância com a Declaração de Estocolmo (1972), a qual estabelece que "deve ser confiada às instituições nacionais competentes a tarefa de planificar, administrar e controlar a utilização dos recursos ambientais dos Estados, com o fim de melhorar a qualidade do meio ambiente", bem como com o Princípio 11 da Declaração do Rio de Janeiro (1992): "Os Estados deverão promulgar leis eficazes sobre o meio ambiente".

Verifica-se ainda que a proteção ao meio ambiente se reflete tanto na Constituição do Estado de São Paulo como no Plano Diretor do Município de São Paulo.

$\mathrm{Na}$ Constituição Estadual (São Paulo, 1989a) observa-se a proteção ao meio ambiente com a sua consequente fiscalização, nos dispositivos a seguir transcritos:

Artigo 152 - A organização regional do Estado tem por objetivo promover:

III - A utilização racional do território, dos recursos naturais, culturais e a proteção do meio ambiente, mediante o controle da implantação dos empreendimentos públicos e privados na região;

Artigo 191 - O Estado e os Municípios providenciarão, com a participação da coletividade, a preservação, conservação, defesa, recuperação e melhoria do meio ambiente natural, artificial e do trabalho, atendidas as peculiaridades regionais e locais e em harmonia com o desenvolvimento social e econômico.

Artigo 192 - A execução de obras, atividades, processos produtivos e empreendimentos e a exploração de recursos naturais de qualquer espécie, quer pelo setor público, quer pelo privado, serão admitidas se houver resguardo do meio ambiente ecologicamente equilibrado.

No Plano Diretor do Município de São Paulo (São Paulo, 2014) pode-se observar já no Art. $5^{\circ}$ a importância do Meio Ambiente ecologicamente equilibrado, o qual deverá ser protegido na elaboração das políticas públicas, bem como no desenvolvimento privado na cidade. Para tanto, transcreve-se o artigo:

Art. $5^{\circ}$ Os princípios que regem a Política de Desenvolvimento Urbano e o Plano Diretor Estratégico são:

VI - Direito ao Meio Ambiente Ecologicamente Equilibrado;

$\S 6^{\circ}$ Direito ao Meio Ambiente Ecologicamente Equilibrado é o direito sobre o patrimônio ambiental, bem de uso comum e essencial à sadia qualidade de vida, constituído por elementos do sistema ambiental natural e do sistema urbano de forma que estes se organizem equilibradamente para a melhoria da qualidade ambiental e bem-estar humano.

Demonstra-se ainda que no Plano Diretor, o Meio Ambiente corresponderá a uma das sete vertentes de desenvolvimento do Município. 


\subsubsection{Do Direito Administrativo}

A partir do estudo do Direito Administrativo podemos extrair dois conceitos fundamentais para o desenvolvimento do tema. O primeiro deles trata-se do poder de polícia, em especial o poder de polícia exercido pelo Poder Legislativo, no que tange as limitações administrativas ao exercício das liberdades públicas visando assim à supremacia do interesse público.

O segundo conceito está relacionado com a intervenção do Estado no domínio econômico especialmente no que tange ao desenvolvimento de atividades específicas em determinada região.

\subsubsection{Do Poder de Polícia}

O conceito de poder de polícia apresenta um confronto entre dois aspectos fundamentais. O primeiro deles consiste no exercício das liberdades individuais e ao uso da propriedade e o segundo corresponde ao exercício da atividade da Administração visando o bem-estar coletivo e a supremacia do interesse público.

O confronto apontado se dá no limite de que o exercício da atividade da Administração limita o exercício das liberdades individuais e o uso da propriedade. Observa-se, porém, que, conforme aponta Maria Sylvia Z. Di Pietro em seu livro Direito Administrativo, "não existe qualquer incompatibilidade entre os direitos individuais e os limites a eles opostos pelo poder de polícia do Estado porque, como ensina Zanobini (1968, v. 4:191), "a ideia de limite surge do próprio conceito de direito subjetivo: tudo aquilo que é juridicamente garantido é também juridicamente limitado" (Di Pietro, 2013, p. 120).

Na visão de Celso Antônio Bandeira de Mello, em seu Curso de Direito Administrativo, "é necessário que o uso da liberdade e da propriedade esteja entrosado com a utilidade coletiva, de tal modo que não implique uma barreira capaz de obstar à realização dos objetivos públicos" (Mello, 2015, p.842).

Colocados esses aspectos, é necessário se delimitar o conceito de poder de polícia. Segundo Di Pietro o poder de polícia, em seu conceito moderno, representaria "a atividade do Estado consistente em limitar o exercício dos direitos individuais em benefício do interesse público" (Di Pietro, 2013, p. 123). Observa-se que o interesse público abrangeria uma gama grande de setores da sociedade, dentre eles segurança, moral, saúde, defesa do consumidor, patrimônio e, um dos objetos deste trabalho, o meio ambiente.

Nessa mesma linha, Celso Antônio Bandeira de Mello apontou que "a atividade estatal de condicionar a liberdade e a propriedade ajustando-as aos interesses coletivos designa-se "poder de polícia" (Mello, 2015, p.846), sendo que em sentido amplo abrangeria tanto atos do Legislativo quanto do Executivo. Em outras palavras caracteriza-se pelo complexo de medidas estatais que delineiam a esfera juridicamente tutelada da liberdade e da propriedade dos cidadãos.

Em sentido estrito, por sua vez, o poder de polícia estaria relacionado com as intervenções, sejam elas gerais ou abstratas, do Poder Executivo, destinando-se novamente a prevenir e obstar o desenvolvimento de atividades particulares contrastantes com os interesses sociais.

A atuação do poder de polícia, para fins deste trabalho, corresponderia aos atos normativos em geral (por lei), os quais ensejariam em limitações administrativas aos jurisdicionados no exercício de seus direitos e atividades individuais (liberdades individuais e direito a propriedade), "estabelecendo-se normas gerais e abstratas dirigidas indistintamente às pessoas que estejam em idêntica situação" (Di Pietro, 2013, p. 125). Em complemento a essa atuação legislativa, o Executivo poderá baixar decretos, resoluções, portarias e instruções disciplinando a aplicação da lei aos casos concretos.

Observa-se ainda um segundo meio de atuação do poder de polícia, que corresponde aos atos administrativos e operações materiais de aplicação da lei ao caso concreto, compreendendo assim medidas preventivas, em especial fiscalização e vistoria, e medidas repressivas (interdição da atividade, apreensão de mercadorias, demolição), com a finalidade de coagir o infrator a cumprir a lei. 


\subsubsection{Da intervenção do Estado no domínio econômico}

Como observado no item anterior, o legislador brasileiro fixou na Administração Pública a necessidade de atuar, por meio do poder de polícia, com o objetivo de preservar o interesse público, limitando-se esta atuação aos termos previstos em lei. Ressalva-se, porém, que essa intervenção não se restringe ao poder de polícia, existindo, portanto, outras formas de intervenção.

Segundo Celso Antônio Bandeira de Mello, a interferência do Estado na ordem econômica poderá ocorrer de três modos: a) "através de seu "poder de polícia", isto é, mediante leis e atos administrativos expedidos para executá-las, como "agente normativo e regulador da atividade econômica" - caso no qual exercerá funções de "fiscalização" e em que o "planejamento" que conceber será meramente "indicativo para o setor privado" e "determinante para o setor público"(Mello, 2015, p. 818), conforme a previsão do Art. 174 da Constituição Federal (Brasil, 1988); b) sendo ele próprio atuante, em casos excepcionais, conforme previsto no $\S 1^{\circ}$ do Art. 173 da Constituição Federal (Brasil, 1988), mediante pessoas que cria com tal objetivo; c) atuando por meio de incentivos à iniciativa privada, estimulando-a com favores fiscais e/ou financiamentos.

A primeira das formas de intervenção estatal consiste no exercício do poder de polícia, em especial, pelo Legislativo, no que tange a elaboração de leis voltadas ao desenvolvimento ou restrição do desenvolvimento do exercício da atividade econômica, principalmente se essa atividade for em oposição a um dos princípios previstos no Art. 170 da Constituição Federal (Brasil, 1988). Por sua vez, a atividade fiscalizatória ficará a cargo do poder de polícia a ser exercido pela Administração Pública, observando para tal fiscalização os primados constitucionais.

A segunda forma de intervenção, a qual não é objeto deste estudo, caracteriza-se pela intervenção propriamente dita da Administração Pública, ou de seus entes, no domínio econômico, uma vez que ela passa a participar do mercado não mais como uma força fiscalizadora e/ou regulamentadora, mas sim de uma forma mais participativa, agindo como um ente privado. Sendo, portanto, uma modalidade de intervenção mais incisiva por parte do Estado no domínio econômico.

A terceira forma de intervenção estatal, conforme a classificação de Celso Antônio Bandeira de Mello (Mello, 2015), consiste na atuação do ente público como um estimulador ao desenvolvimento de determinadas atividades em algumas regiões. Tal intervenção ocorre por meio de estímulos fiscais, como, por exemplo, diminuição de determinados impostos para determinada atividade; e por meio de financiamentos, tal como por meio de programas de microcrédito, por meio de agencia de fomento estadual (ex: Desenvolve SP) ou até por meio de Banco de Desenvolvimento (ex: BNDES).

Por fim, ressalta-se que as intervenções que ocorrerem, seja por qualquer uma dessas três modalidades, deverão observar os preceitos legais, visando principalmente a garantia dos interesses da coletividade, mas observando também a necessidade de se preservar os direitos individuais bem como o direito à propriedade.

\subsubsection{Do Direito Urbanístico}

Das áreas do Direito aqui apresentadas, o Direito Urbanístico corresponde a mais nova a se firmar no Direito como um sistema próprio. Tal brevidade decorre do fato de que esta área do Direito passou a ter relevância com o processo histórico de transição da Idade Média para a Idade Moderna, o qual foi caracterizado pelo ressurgimento das cidades na Europa. Nesse período surgiram algumas normas jurídicas urbanísticas, em especial voltadas para construções urbanas. Acompanhando o desenvolvimento destas normas temos a formação de uma nova seara do Direito, consistindo assim em oferecer ao Poder Público instrumentos normativos com o fim de atuar no meio social e no domínio privado, para ordenar a realidade no interesse da coletividade (Silva, 2015). 
COELHO, A.R.E.P. Represa Guarapiranga: Direito à Moradia e a um Meio Ambiente Equilibrado.

Passados estes aspectos primordiais tanto do urbanismo, bem como do Direito Urbanístico, vemos o desenvolvimento de teorias voltadas para o desenvolvimento ordenado das cidades, as quais privilegiavam certos aspectos em detrimento de outros. O ápice destas teorias se deu com a elaboração da Carta de Atenas (1933), a qual serviu como base para o desenvolvimento do conceito de urbanismo moderno e da qual se é extraído os principais fundamentos para a elaboração das normas de Direito Urbanístico no Ocidente e, em especial no Brasil.

Em uma visão simplista, a Carta de Atenas (1933) entende as cidades como um organismo a ser concebido de forma funcional a fim de garantir aos seus residentes os seus desenvolvimentos plenos. Neste sentido, foram extraídas quatro funções sociais das cidades, as quais deverão ser desenvolvidas a atingir este objetivo. As funções são: trabalhar, morar, divertir e circular, sem as quais os residentes não conseguiram desenvolver o seu bem-estar na plenitude.

O conceito de funções sociais da cidade foi recepcionado pela Constituição Federal (Brasil, 1988) sendo materializado pelo Art. 182 como segue:

Art. 182. A política de desenvolvimento urbano, executada pelo Poder Público municipal, conforme diretrizes gerais fixadas em lei, tem por objetivo ordenar o pleno desenvolvimento das funções sociais da cidade e garantir o bem-estar de seus habitantes.

Observa-se, portanto, que para garantir os objetivos da política urbana, é necessário se trabalhar as funções da cidade, buscando um equilíbrio e desenvolvimento entre elas.

Para se atingir esses objetivos, devemos verificar um segundo conceito do Direito Urbanístico, que é o conceito da função da propriedade urbana. Esta função da propriedade somente é atingida quando a propriedade é utilizada de modo a cumprir a sua previsão dentro do previsto no ordenamento municipal, que no caso em espécie desse estudo seria o Plano Diretor Estratégico do Município de São Paulo (São Paulo, 2014), podendo o poder público utilizar de instrumentos previstos no próprio plano para garantir que o particular atue no sentido de que sua propriedade cumpra a sua função social. Neste sentido temos os parágrafos $2^{\circ}$ à $4^{\circ}$ do Art. 182:

$\S 2^{\circ}$ A propriedade urbana cumpre sua função social quando atende às exigências fundamentais de ordenação da cidade expressas no plano diretor.

$\S 3^{\circ}$ As desapropriações de imóveis urbanos serão feitas com prévia e justa indenização em dinheiro.

$\S 4^{\circ}$ É facultado ao Poder Público municipal, mediante lei específica para área incluída no plano diretor, exigir, nos termos da lei federal, do proprietário do solo urbano não edificado, subutilizado ou não utilizado, que promova seu adequado aproveitamento, sob pena, sucessivamente, de:

I - Parcelamento ou edificação compulsórios;

II - Imposto sobre a propriedade predial e territorial urbana progressivo no tempo;

III - Desapropriação com pagamento mediante títulos da dívida pública de emissão previamente aprovada pelo Senado Federal, com prazo de resgate de até dez anos, em parcelas anuais, iguais e sucessivas, assegurados o valor real da indenização e os juros legais.

Posto isto, faz-se necessário analisar a Carta de Atenas (1933), bem como dois dos direitos elencados como funções da cidade e que estão relacionados intimamente com o tema desse estudo, que são o Direito à Moradia e o Direito ao Lazer. 


\subsubsection{Carta de Atenas (1933)}

A Carta de Atenas (1933) é um manifesto firmado no $4^{\circ}$ Congresso Internacional de Arquitetura Moderna, que ocorreu em Atenas, na Grécia. O referido Congresso buscou um debate voltado para o planejamento regional e infra urbano da ocupação e uso do solo.

Segundo este manifesto, o zoneamento das cidades deveria ser feito de modo a separar os diferentes tipos de uso do solo em zonas distintas, evitando assim o conflito de usos incompatíveis. Nesta linha, o Estado teria grande importância, uma vez que seria o responsável por fiscalizar e ordenar tal desenvolvimento das zonas.

De acordo com o documento, as principais cidades do mundo Ocidental naquela época apresentavam uma desordem que acabava por atingir negativamente o próprio habitante, uma vez que o afetava tanto fisicamente quanto moralmente, e que tal desordem era consequência dos crescentes interesses privados sobre as propriedades, acarretando em transformações constantes, mas desordenadas.

Por sua vez, aponta o documento, o desenvolvimento das cidades deveria observar as quatro funções da cidade, a fim de garantir o bem estar de seus habitantes. Primeiramente, assegurar aos homens moradias saudáveis, isto é, locais onde o espaço, o ar puro e o sol sejam assegurados de forma plena; em seguida, organizar os locais de trabalho, de tal modo que eles tornem a referida atividade como algo humanamente natural; em terceiro, fixar locais que poderão ser utilizados nas horas livres, por fim, a quarta função corresponde à rede de circulação.

Para a garantia dessas funções, bem como para garantir os objetivos de desenvolvimento humano, aponta o documento para a subordinação do interesse individual em face do interesse coletivo, devendo tal subordinação ocorrer por meio de atuação do poder público, o qual atuaria através do Direito Urbanístico.

Neste sentido e trazendo para o contexto brasileiro, as funções da cidade estão previstas tanto na Constituição Federal, (Art. 182, Brasil, 1988), como na Legislação Federal, o Estatuto da Cidade (Brasil, 2001) e na Legislação Municipal - Plano Diretor (São Paulo, 2014). Porém diferentemente do desejado pelos elaboradores da Carta de Atenas, a subordinação do particular em face do coletivo não ocorreu de forma plena, sendo facultado ao particular uma certa liberalidade quanto à ocupação do solo principalmente nas regiões de zoneamento misto.

\subsubsection{Do Direito à Moradia}

O artigo $6^{\circ}$ da Constituição Federal (Brasil, 1988) apresenta a vocação do direito à moradia como direito social na sistemática jurídica brasileira, sendo que sua previsão somente foi positivada de forma expressa na Constituição com a Emenda Constitucional n 26 de 2000 (Brasil, 2000), caracterizado como decorrente principalmente dos princípios da proteção à vida e a dignidade da pessoa humana, conforme destaque que segue.

Art. 6 ${ }^{\circ}$ : São direitos sociais a educação, a saúde, a alimentação, o trabalho, a moradia, o transporte, o lazer, a segurança, a previdência social, a proteção à maternidade e à infância, a assistência aos desamparados, na forma desta Constituição. (grifo do autor).

Observa-se, porém, que o referido direito adentrou na sistemática jurídica brasileira em 1992 por meio dos Decretos Presidenciais n 591 e n 592 (Brasil, 1992a, b), os quais ratificaram o Pacto Internacional sobre Direitos Econômicos, Sociais e Culturais e o Pacto Internacional de Direitos Civis e Políticos, respectivamente. Em ambos os documentos havia a previsão expressa de proteção ao direito à moradia e já avançavam quanto a este direito ao prever que para sua plena efetivação, o ser humano deveria ter uma moradia digna.

A previsão constitucional deste direito feita pela Emenda Constitucional no 26/2000 (Brasil, 2000) fixou de modo claro a necessidade de observa-lo quando da elaboração de políticas públicas, cabendo, por sua 
vez, o desenvolvimento desta por meio da legislação infraconstitucional e jurisprudencial, se destacando os aspectos de segurança jurídica da posse, disponibilidade de infraestrutura básica capaz de assegurar condições de habitabilidade, o acesso a serviços essenciais, porém não se afastando dos conceitos originários de proteção à vida e dignidade da pessoa humana.

Nesse sentido, conforme Ingo Wolfgang Sarlet no livro Curso de Direito Constitucional, "o direito à moradia se traduz em direitos subjetivos à construção, pelo Poder Público, de uma moradia digna (ainda que não na condição de propriedade), ou, em caráter alternativo, em direito (exigível) de fornecimento de recursos para tanto ou para, por exemplo, obras que assegurem à moradia sua condição de habitabilidade, sem prejuízo de todo um leque de aspectos a serem exploradas na seara do direito à moradia na perspectiva de sua função de direito a prestações..." (Sarlet, 2013, p. 604).

A garantia deste direito também deveria ser observada quanto a localização das moradias, em especial daquelas localizadas em áreas de risco tanto para os próprios moradores, como por exemplo, moradias em encostas, em áreas de reiteradas enchentes; como para a sociedade em sentido amplo, a exemplo do caso de moradias localizadas em áreas de proteção ambiental ou em borda de rios e mananciais, uma vez que devido à falta de saneamento básico, acabam por contaminar as referidas regiões.

Como se verá mais adiante, a legislação vigente demonstrou um avanço neste sentido ao reconhecer as regiões que apresentam riscos às moradias, tendo em vista a sua localização, apresentando assim mecanismos a serem utilizados para uma realocação destas em regiões com menores riscos; bem como reconheceu a necessidade de a Administração Pública prover uma melhor infraestrutura, garantindo assim moradias dignas. Há de ressaltar que as principais normas jurídicas a tratarem deste tema são as municipais, tanto por força da competência fixada pela Constituição Federal, bem como por se tratar do ente público que mais próximo se encontra do cidadão, tendo assim mais facilidade para receber seus anseios e tomar medidas para atendê-los.

\subsubsection{Do Direito ao Lazer}

O direito ao lazer também compreende um dos direitos elencados pelo Art. $6^{\circ}$ da Constituição Federal (Brasil, 1988) e que foram introduzidos pela Emenda Constitucional n ${ }^{\circ}$ 26/2000 (Brasil, 2000).

O direito ao lazer compreende tanto um direito social como um elemento de saúde pública, uma vez que sua não fruição pode ocasionar em danos à saúde da população. Tanto o é que na própria Consolidação das Leis do Trabalho havia a previsão no Art. 428 de se incentivar a prática de atividades nas horas de lazer, a fim de propiciar um desenvolvimento físico, moral e psicológico do aprendiz (Brasil, 1943), destacando-se assim a importância deste direito. Tal previsão veio a ser alterada em 2004 com a nova redação do artigo acima citado.

Observa-se ainda que este mesmo direito encontrava-se presente na Carta de Atenas (1933), sendo reconhecido como uma das funções da cidade e vislumbrando no sentido de proporcionar aos habitantes condições para que eles atingissem a plenitude de seu potencial.

Há de se observar ainda que a despeito da inclusão por meio da Emenda Constitucional nº 26/2000 (Brasil, 2000) já havia a previsão de garantia deste direito por força do Art. $7^{\circ}$ do Pacto Internacional sobre Direitos Econômicos, Sociais e Culturais (Brasil, 1992a) o qual tem a seguinte redação:

"Pacto Internacional sobre Direitos Econômicos, Sociais e Culturais" Artigo $7^{\circ}$

Os Estados Partes do presente Pacto reconhecem o direito de toda pessoa de gozar de condições de trabalho justas e favoráveis, que assegurem especialmente:

a) Uma remuneração que proporcione, no mínimo, a todos os trabalhadores:

i) Um salário equitativo e uma remuneração igual por um trabalho de igual valor, sem qualquer distinção; em particular, as mulheres deverão ter a garantia de condições de trabalho não inferiores às dos homens e perceber a mesma remuneração que eles por trabalho igual; 
ii) Uma existência decente para eles e suas famílias, em conformidade com as disposições do presente Pacto;

b) A segurança e a higiene no trabalho;

c) Igual oportunidade para todos de serem promovidos, em seu Trabalho, à categoria superior que lhes corresponda, sem outras considerações que as de tempo de trabalho e capacidade;

d) O descanso, o lazer, a limitação razoável das horas de trabalho e férias periódicas remuneradas, assim como a remuneração dos feriados. (grifo do autor).

Observando o caráter amplo do direito ao Lazer temos o destaque feito por Ingo Wolfgang Sarlet:

“... o direito ao lazer estaria vinculado aos direitos à cultura e ao desporto, seja na efetivação do direito à educação, ao permitir uma formação mais ampla das crianças e dos adolescentes, seja na concretização de políticas públicas de garantia de qualidade de vida ao idoso. O direito ao lazer, por outro lado, dialoga com o conceito de saúde como "estado de completo bem-estar físico, mental e social" (OMS), justificando, por isso, que possa integrar o conteúdo do mínimo existencial e da própria vida com dignidade, já que essencial à vida com (alguma) qualidade, pois se cuida de exigência para o próprio desenvolvimento (com plenitude) da personalidade humana." (Sarlet, 2013, p.618).

Por fim, vale ressaltar que a efetivação deste direito por parte da Administração Pública pode ocorrer de diversas formas, dentre elas a promoção de atividades, realização de eventos e implantação de equipamentos públicos (bibliotecas, espaço para eventos, parques, etc.).

\subsection{DA COMPETÊNCIA PARA LEGISLAR}

A definição da competência de cada ente da federação é obtida através de análise sobre a Constituição Federal, nesse sentido há de se delimitar as áreas de atuação do objeto deste estudo.

Este estudo teve como objeto apontar alguns dos conflitos socioambientais decorrentes da ocupação da borda da Represa do Guarapiranga. Deste modo, as macro áreas do Direito que possuem uma maior relevância para este tema, são as do Direito Ambiental, em especial quanto a destinação da borda da represa, e do Direito Urbanístico, uma vez que trata da ordenação da ocupação do solo da borda da represa, sendo que esta se encontra inserida na Região Metropolitana de São Paulo e teve ligação histórica com o crescimento do Município de São Paulo, em especial dos bairros que a circundam.

\subsubsection{Competência da União}

A competência da União de legislar nas matérias de Direito Ambiental e Direito Urbanístico vem disposta de modo principal nos Art. 21 a 24 da Constituição Federal (Brasil, 1988). Observa-se, que, quanto a estas matérias não temos a competência privativa da União, mas sim de um sistema que envolve os três entes da federação, cabendo a União fixar diretrizes, quanto ao Direito Urbanístico, e limitações mínimas quanto ao Direito Ambiental.

Em relação ao Direito Ambiental temos a Lei Federal nº 6938/81 a qual trata da Política Nacional de Meio Ambiente - PNMA (Brasil, 1981), e os Art. 23, incisos VI e VII e Art. 24, inciso VI, os quais serviram como norteadores em conjunto com o Art. 225, todos da Constituição Federal (Brasil, 1988), para o desenvolvimento de políticas nesta seara. 
Por sua vez, conforme fixou o Art. 21, inciso IX, da Constituição Federal (Brasil, 1988), a União deverá elaborar e executar planos nacionais e regionais de ordenação territorial e de desenvolvimento social e econômico. Quanto à referida delimitação, há de se observar que a sua influência seria muito restrita quanto ao desenvolvimento local, sendo, portanto, voltada ao desenvolvimento macro. Observa-se, porém, no mesmo artigo, inciso XX, que temos a competência da União de instituir diretrizes para o desenvolvimento urbano e, nesta linha, o Art. 24, inciso I e $\S 1^{\circ}$ reforça a atuação da União de forma a estabelecer regras genéricas, sob o risco de adentrar na competência dos demais entes da federação.

\subsubsection{Competência dos Estados}

Aos Estados da Federação, conforme o Art. 24 e seus incisos I e VI, bem como seus parágrafos $2^{\circ}$, $3^{\circ}$ e $4^{\circ}$, da Constituição Federal (Brasil, 1988), restou a competência suplementar quanto a função legislativa em relação à matéria de Direito Urbanístico e Ambiental. Ressalva-se ainda que, inexistindo legislação federal sob o tema, os Estados têm competência legislativa plena de exercê-la e, a partir da leitura do $\S 4^{\circ}$, os Estados podem legislar de modo mais restritivo que a União, atendendo as suas peculiaridades. Nesse sentido temos a Política Estadual do Meio Ambiente do Estado de São Paulo, a qual é tratada pela Lei Estadual no 9.509 de 1997 (São Paulo, 1997a).

No aspecto do Direito Urbanístico, José Afonso da Silva delimita a atuação da função legislativa estadual nos seguintes termos:

"A Constituição vigente eliminou a discussão, ao lhes atribuir competência concorrente com a União para legislar sobre direito urbanístico - o que significa, nos termos do art. 24, I e seus $\S \S$, que lhes cabe dispor suplementarmente sobre a matéria, (...) Abre-se aos Estados, aí, no mínimo, a possibilidade de estabelecer normas de coordenação dos planos urbanísticos ao nível de suas regiões, além de sua expressa competência para estabelecer regiões metropolitanas (art. 25, $3^{\circ}$ ). " (Silva, 2015, p. 124).

\subsubsection{Competência dos Municípios}

A competência municipal no que tange a seara ambiental é complementar às legislações federal e estadual, cabendo assim ao Município integrar a sistemática nacional de proteção ao meio ambiente, seja elaborando uma legislação mais restritiva, seja promovendo uma fiscalização local, em especial no que tange a realização de grandes obras.

No aspecto do Direito Urbanístico, o Município é o principal agente legislador, recebendo uma proteção por parte da Constituição Federal quanto a sua área de atuação.

A referida proteção feita pela Constituição Federal (Brasil, 1988) pode ser encontrada tanto nos incisos II, VI e IX do Art. 23 e nos incisos I, VI e VII do Art. 24, quanto nos Art. 30 e 182. Os Art. 23 e 24 da Constituição Federal tratam da competência comum e concorrente, respectivamente, dos entes legislativos. Por sua vez, os Art. 30 e 182 são claros na visão do Município como principal agente de atuação nesta área, em especial por ser o ente mais próximo da realidade fática.

Neste sentido ressalta José Afonso da Silva:

“(...) aos Municípios cabe estabelecer a política de desenvolvimento urbano, com o objetivo de ordenar o pleno desenvolvimento das funções sociais da cidade e garantir o bem-estar de seus habitantes (art. 182), promover o adequado ordenamento do seu território, mediante o planejamento e o controle do uso, parcelamento e da ocupação do solo urbano, elaborando e executando, para tanto, o plano diretor (art. 30, VIII). A competência municipal não é 
meramente suplementar de normas gerais federais ou de normas estaduais, pois não são criadas com fundamento no art. 30, II. Trata-se de competência própria que vem no texto constitucional." (Silva, 2015, p. 63).

Nessa linha José Afonso da Silva continua:

"Em verdade, as normas urbanísticas municipais são as mais características, porque é nos Municípios que se manifesta a atividade urbanística na sua forma mais concreta e dinâmica. Por isso, as competências da União e do Estado esbarram na competência própria que a Constituição reservou aos Municípios, embora estes tenham, por outro lado, que conformar sua atuação urbanística aos ditames, diretrizes e objetivos gerais do desenvolvimento urbano estabelecido pela União e às regras genéricas de coordenação expedidas pelo Estado." (Silva, 2015, p. 63).

Observa-se que o autor faz uma ressalva quanto às matérias que envolvem o meio ambiente, caracterizando a atuação legislativa como suplementar a legislação federal e estadual.

\subsection{DO ASPECTO HISTÓRICO E JURÍDICO DA REPRESA GUARAPIRANGA}

Para entender a atual situação da Represa Guarapiranga é necessário fazer uma retrospectiva histórica tanto do desenvolvimento da região que cerca o manancial, bem como da evolução da legislação sobre a própria represa e da ocupação do seu entorno.

\subsubsection{Da evolução histórica e jurídica da Represa Guarapiranga}

Para se entender os motivos que ensejaram a instalação da Represa Guarapiranga, faz-se necessário retroceder ao ano de 1899. Nesse ano é assinado o Decreto Federal no 3.349/1899 (Brasil, 1899), que autorizou a empresa The São Paulo Railway Light and Power Company Limited (Light) a funcionar no Brasil, atuando principalmente na exploração dos serviços de produção e distribuição de energia elétrica, serviço de iluminação e de transporte coletivo. Em 1901, esta empresa conclui a instalação da Usina Hidrelétrica de Santana de Parnaíba, a qual utilizaria as águas do rio Tietê para a geração de energia, deste modo a produção de energia somente estaria comprometida nos períodos de estiagem, que viessem a atingir a região superior do rio.

Com o intuito de regular a vazão do rio Tietê e aumentar a capacidade de geração da Usina de Santana, estudou-se a construção de um lago artificial em um de seus afluentes. Foi selecionado para este fim o rio Guarapiranga em razão de fatores técnicos (matéria prima, terras de baixo valor econômico) além de já existir à época uma ligação entre o município de São Paulo e município de Santo Amaro (incorporado posteriormente ao município de São Paulo). Observa-se nesse sentido a Lei Estadual nº 1.061-B de 1906 (São Paulo, 1906), a qual concedeu benefícios a Light para que promovesse o necessário para a instalação do lago artificial, incluindo para tanto a desapropriação das áreas a serem alagadas.

Com a conclusão das obras em 1909, os bairros de seu entorno passaram por grandes transformações em decorrência da função recreativa que a represa assumiu, atraindo para região muitos visitantes. Tal função acabou por ser uma força motriz de ordenação da ocupação do solo na região, trazendo vários bares e clubes para a região e servindo também como um instrumento de atração de infraestrutura, tendo como exemplo a linha de bonde instalada entre o centro de Santo Amaro e São Paulo.

O uso exclusivo das águas da represa para geração de energia elétrica ocorreu até meados de 1927 quando começaram estudos para a captação de água para o fornecimento à capital. Os referidos estudos 
COELHO, A.R.E.P. Represa Guarapiranga: Direito à Moradia e a um Meio Ambiente Equilibrado.

baseavam-se na nova realidade que a capital vivenciava, com constantes períodos de estiagem, bem como no projeto de instalação de uma usina hidrelétrica em Cubatão, a qual obrigaria a retificação e o represamento do rio Pinheiros e seus tributários.

Com a conclusão dos estudos sobre a captação das águas para abastecimento, e em decorrência de acordos para a instalação da usina de Cubatão, foi aprovado o Decreto Estadual no 4.487/1928 (São Paulo, 1928), o qual permitia ao Governo Estadual retirar até 4 metros cúbicos por segundo do reservatório para o abastecimento da Capital. Observa-se ainda que este decreto já promovia algumas medidas de conservação destas águas, uma vez que obrigava a Light a tomar medidas com fim de evitar a proliferação de larvas e ninfas que poderiam ser nocivas a saúde pública, bem como manter as condições de saneamento das águas.

Deste modo, após a conclusão das obras da primeira adutora em 1929, as águas da represa passavam a servir para a geração de energia e abastecimento de água da Capital.

Passados quase 10 anos do uso das águas da represa para abastecimento, foi constatado pela Repartição de Águas e Esgotos da Capital (RAE), empresa responsável à época pela gestão do saneamento em São Paulo, um aumento na poluição das mesmas e apontado como motivo para tal fato a ocupação e povoamento das margens do reservatório. Como solução apontada pelo relatório da RAE, temos a necessidade de criação de uma legislação voltada para a proteção das águas (estadual) como também para a proteção de suas margens em face da ocupação humana (municipal), porém nenhuma dessas medidas foi adotada até a década de 1960 (SABESP, 2008).

Com o aumento da dependência do abastecimento da capital com as águas do Sistema Guarapiranga, o aspecto da poluição de suas águas passou a ter maior importância, sendo de conhecimento dos órgãos governamentais que a ocupação das margens era um dos fatores responsáveis por esta poluição. Neste sentido foi criada a Comissão da Bacia do Guarapiranga, por meio da Resolução no 1.180/1960 (SABESP, 2008), tendo como finalidade estudar e propor medidas destinadas à instituição de zoneamento do entorno do manancial, bem como assegurar condições sanitárias e de potabilidade das águas do reservatório.

Observa-se ainda que no período de 1940 a 1960, o bairro de Santo Amaro passou por um forte desenvolvimento, favorecido em especial pela fixação do parque industrial de Santo Amaro, bem como a implantação de grandes obras de infraestrutura/mobilidade, como as vias marginais ao Rio Pinheiros. Tal desenvolvimento provocou uma demanda por habitação, gerando assim mais pressão para ocupação das bordas da Represa Guarapiranga.

A década de 1970, por sua vez, representou uma tentativa de regulamentar a ocupação do solo na região dos mananciais paulistas. Tal relevância se deve as Leis Estaduais no 898/75 (São Paulo, 1975) e $n^{\circ}$ 1.172/76 (São Paulo, 1976) que visavam gerir a associação entre o uso do solo e a qualidade das águas destinadas ao abastecimento humano. A Lei $n^{\circ}$ 898/75 disciplinava o uso do solo para proteção dos mananciais, estabelecendo para tanto critérios legais para este tipo de ocupação. Já a Lei $\mathrm{n}^{0} 1.172 / 76$, a qual foi regulamentada pelo Decreto Estadual n ${ }^{\circ}$ 47.696/2003 (São Paulo, 2003), tratou de delimitar as áreas de mananciais e estabeleceu normas de restrição ao uso do solo nas referidas regiões.

A legislação destacada poderia ter representado um avanço na regulamentação da ocupação do solo, mas, em termos práticos, foi um facilitador na ocupação desordenada. Tal afirmativa se deve ao fato de que a referida legislação, por ser mais restritiva, ocasionou na desvalorização dos terrenos e isto, aliado a falta de fiscalização quanto a ocupação fundiária, bem como a um déficit de moradias para as classes mais populares, acabaram por servir como um atrativo para a vinda de mais famílias as estas regiões.

Ciente de que a legislação não surtiu o efeito desejado e com o intuito de no mínimo estabilizar este quadro, foi promulgada em 1997 a Lei Estadual no 9.866/1997 (São Paulo, 1997b), a qual reconheceu a existência da ocupação irregular na área dos mananciais e estabeleceu o princípio de recuperação das áreas degradadas. A referida lei representou um avanço por reconhecer a situação crítica que se encontravam os mananciais paulistas, em especial os sistemas Billings e Guarapiranga. Em complemento a esta lei, e com o intuito de se aproximar mais da complexidade que se encontrava o manancial do Guarapiranga, foi promulgada 
a Lei Estadual n ${ }^{0}$ 12.233/2006 (São Paulo, 2006). Esta lei define a área de proteção bem como as medidas para recuperação do manancial e de seu entorno, representando assim um avanço na tentativa de se reverter o quadro vigente quanto à ocupação do solo.

Observa-se ainda que o interesse estadual recente de recuperação do manancial se deu em conjunto com as mudanças de legislação na esfera municipal, bem como com o aumento da fiscalização quanto à ocupação irregular.

\subsubsection{Da Legislação Vigente}

Para a apresentação da legislação vigente em relação a normatividade do Direito Urbanístico e do Direito Ambiental no que tange a região da Represa Guarapiranga, que é o objeto deste trabalho, torna-se necessário ter como ponto de partida a própria Constituição Federal, a qual fixou a competência de cada ente da Federação na seara legislativa.

No aspecto Urbanístico, a competência da União nesta matéria se dará por meio de fixação de diretrizes, as quais deverão ser observadas pelos demais entes no momento de elaboração de suas respectivas normas. Neste sentido temos o inciso I e o $\S 1^{\circ}$ do Art. 24 da Constituição Federal (Brasil, 1988), o qual estabeleceu que "a competência da União limitar-se-á a estabelecer normas gerais" nesta matéria.

Posto isto, vemos que o exercício da competência de legislar da União fixada pela Carta Magna se deu por meio da Lei Federal n ${ }^{\circ}$ 10.257/2001 (Brasil, 2001), denominada de Estatuto das Cidades. Segundo José Afonso da Silva "O Estatuto da Cidade, (...) estabelece as diretrizes gerais da política urbana, que tem como objetivo ordenar o pleno desenvolvimento das funções sociais da cidade e da propriedade urbana em prol do bem coletivo, da segurança e do bem-estar dos cidadãos, bem como o equilíbrio ambiental" (Silva, 2015, p. $58)$.

Quanto à referida lei José Afonso da Silva continua:

“Assume ele, assim, as características de uma lei geral de direito urbanístico, talvez com certo casuísmo exagerado. Assim mesmo, cumpre ele as funções supra indicadas de uma lei geral, na medida em que institui princípios de direito urbanístico, disciplina diversas figuras e institutos do direito urbanístico, fornece um instrumental a ser utilizado na ordenação dos espaços urbanos, com observância da proteção ambiental, e a busca de soluções para problemas sociais graves, como a moradia, o saneamento, que o caos urbano faz incidir, de modo contundente, sobre as camadas carentes da população" (Silva, 2015, p.67).

Por sua vez, tendo em vista que em termos urbanísticos a competência estadual é suplementar a legislação federal, conforme previsto nos $\S \S 2^{\circ}$ à $4^{\circ}$ do Art. 24 da Constituição Federal (Brasil, 1988), o legislador estadual atua de modo a impor diretrizes, em especial quanto a ocupação do solo.

Neste sentido temos a Constituição Estadual (São Paulo, 1989a) que, no Capítulo II - Do Desenvolvimento Urbano, do Título VI, apresenta diretrizes para o desenvolvimento urbano no Estado, bem como estabelece a sua competência para legislar quanto as diretrizes para a localização de atividades industriais no estado (Art. 183).

Ainda em relação a legislação estadual e em especial no que tange a região que engloba a região da Bacia Hidrográfica do Guarapiranga, temos a Lei Estadual no 12.233/2006 (São Paulo, 2006) e o Decreto Estadual no 51.686/2007 (São Paulo, 2007), os quais tratam de mecanismos de proteção a este manancial e, em especial no aspecto do Direito Urbanístico, tratam da ocupação do solo das regiões do manancial, impondo limitações quanto a área ocupada e a área possível de ser impermeabilizada. A referida legislação ainda apresenta limitações quanto as atividades que podem ser exercidas em cada subárea por ela fixada.

Como exemplo desta limitação no que tange ao exercício de atividades, temos o $§ 1^{\circ}$ do Art. 35 da Lei Estadual nº 12.233/2006 (São Paulo, 2006), que possui a seguinte redação: 
COELHO, A.R.E.P. Represa Guarapiranga: Direito à Moradia e a um Meio Ambiente Equilibrado.

Artigo 35: São permitidos nas Subáreas Envoltórias da Represa - SER os usos urbanos disciplinados pela legislação municipal de uso e ocupação do solo.

$\S 1^{\circ}$ - Fica proibida nas SER a instalação de empreendimentos industriais.

Já o Art. 30 da mesma lei, que estabelece parâmetros urbanísticos básicos para a instalação de usos urbanos nas Subáreas de Ocupação diferenciada, como se observa:

Artigo 30: Constituem parâmetros urbanísticos básicos para a instalação de usos urbanos, residenciais e não-residenciais, nas Subáreas de Ocupação Diferenciada - SOD:

I - o coeficiente de aproveitamento máximo de 0,3 (três décimos);

II - o índice de impermeabilização máximo de 0,4 (quatro décimos);

III - o lote mínimo de $1.500 \mathrm{~m}^{2}$ (mil e quinhentos metros quadrados).

Por fim, ressalta-se a previsão por parte da Lei Estadual no 12.233/2006 (São Paulo, 2006) da existência de um plano de Desenvolvimento e Proteção Ambiental para todo o manancial, atingindo assim sete municípios e promovendo nestes um ordenamento mínimo na região afetada.

No âmbito da legislação do Município de São Paulo podemos observar uma revisão em relação as normas de direito urbanístico atualmente em vigor. Tal fato se deve com a aprovação, em 2014, do Plano Diretor Estratégico do Município de São Paulo (Lei Municipal no 16.050/2014) (São Paulo, 2014), o qual estabeleceu uma série de diretrizes para revisão do zoneamento paulistano, bem como apresentou uma nova dinâmica para o desenvolvimento da cidade, em especial nas zonas que margeiam os seus principais rios - Tietê, Pinheiros e Tamanduateí, além de apresentar os instrumentos a serem utilizados para a garantia da função social da propriedade.

Com a promulgação do Plano Diretor Estratégico do Município de São Paulo, as leis que eram baseadas no antigo plano diretor estão passando por uma revisão legislativa a fim de se adequarem as disposições do novo plano. Neste sentido, temos a Lei Municipal no 16.402/2016 (Lei de Zoneamento) (São Paulo, 2017), a qual disciplina o parcelamento, o uso e a ocupação do solo no Município de São Paulo, definindo assim as formas de ocupação da cidade.

Há de se observar que o plano diretor, nas palavras de José Afonso da Silva "é, nos termos da Constituição e do Estatuto da Cidade, o instrumento básico da política de desenvolvimento e de expansão urbana" (Silva, 2015, p.137). Neste sentido, ele estabelece os objetivos a serem atingidos, as atividades a serem executadas e quem deve executá-las, fixando ainda as diretrizes do desenvolvimento urbano do Município.

Por sua vez, observa-se que o Plano Diretor Estratégico do Município de São Paulo (São Paulo, 2014), além de representar a principal norma em termos de Direito Urbanístico na municipalidade, também representa um importante instrumento em termos de Direito Ambiental.

Quanto a este aspecto da lei temos o fato de o plano diretor incorporar a agenda ambiental ao desenvolvimento da cidade, estabelecendo normas para a ampliação e preservação de zonas de proteção e preservação ambiental. Neste sentido temos os Art. 194 e 195 do Plano Diretor Estratégico os quais apresentam os objetivos da Política Ambiental Municipal (São Paulo, 2014).

Art. 194. São objetivos da Política Ambiental:

I - Implementação, no território municipal, das diretrizes contidas na Política Nacional de Meio Ambiente, Política Nacional de Recursos Hídricos, Política Nacional de Saneamento Básico, Política Nacional de Resíduos Sólidos, Política Nacional e Municipal de Mudanças Climáticas, Lei Federal da Mata Atlântica, Sistema Nacional de Unidades de Conservação e demais normas e regulamentos federais e estaduais, no que couber;

II - Conservação e recuperação do meio ambiente e da paisagem;

III - Proteção dos serviços ambientais prestados pelos ecossistemas;

IV - Redução da contaminação ambiental em todas as suas formas; 
V - Garantia de proteção dos recursos hídricos e mananciais de abastecimento;

VI - Priorização de medidas de adaptação às mudanças climáticas;

VII - Incentivo à adoção de hábitos, costumes e práticas que visem à proteção dos recursos ambientais;

VIII - Produção e divulgação de informações ambientais organizadas e qualificadas;

IX - Estímulo às construções sustentáveis.

Art. 195. São diretrizes da Política Ambiental:

I - Conservar a biodiversidade, os remanescentes da flora e da fauna;

II - Melhorar a relação de áreas verdes por habitante do Município;

III - Conservar e recuperar a qualidade ambiental dos recursos hídricos, inclusive águas subterrâneas, e das bacias hidrográficas, em especial as dos mananciais de abastecimento;

IV - Aprimorar mecanismos de incentivo à recuperação e proteção ambiental;

V - Criar mecanismos e estratégias para a proteção da fauna silvestre;

VI - Reabilitar as áreas degradadas e reinseri-las na dinâmica urbana;

VII - Minimizar os impactos da urbanização sobre as áreas prestadoras de serviços ambientais;

VIII - Minimizar os processos de erosão e de escorregamentos de solo e rocha;

IX - Contribuir para a redução de enchentes;

$\mathrm{X}$ - Combater a poluição sonora;

XI - Contribuir para a minimização dos efeitos das ilhas de calor e da impermeabilização do solo;

XII - Adotar medidas de adaptação às mudanças climáticas;

XIII - Reduzir as emissões de poluentes atmosféricos e gases de efeito estufa;

XIV - Promover programas de eficiência energética, cogeração de energia e energias renováveis em edificações, iluminação pública e transportes;

XV - Criar, por lei específica, incentivos fiscais e urbanísticos às construções sustentáveis, inclusive na reforma de edificações existentes;

XVI - Adotar procedimentos de aquisição de bens e contratação de serviços pelo Poder Público Municipal com base em critérios de sustentabilidade;

XVII - Estimular a agricultura familiar, urbana e periurbana, incentivando a agricultura orgânica e a diminuição do uso de agrotóxicos;

XVIII - Promover a educação ambiental formal e não formal;

XIX - Articular, no âmbito dos Comitês de Bacias Hidrográficas, ações conjuntas de conservação e recuperação e fiscalização ambiental entre os municípios da Região Metropolitana e a Secretaria Estadual do Meio Ambiente;

XX - Implantar estratégias integradas com outros municípios da Região Metropolitana e articuladas com outras esferas de governo para redução da poluição e degradação do meio ambiente;

XXI - Compatibilizar a proteção ambiental com o desenvolvimento econômico sustentável e a qualidade de vida da população.

Vislumbra-se, portanto, que o próprio legislador municipal reconhece e adota a gama de princípios provenientes tanto da legislação federal quanto da legislação estadual para proteção ao meio ambiente.

Quanto a legislação estadual, no aspecto do direito ambiental, podemos verificar duas leis com preponderância sobre o tema. A primeira delas é a Lei Estadual n 9.866/1997 (São Paulo, 1997b), a qual trata de diretrizes e normas para a proteção e recuperação das bacias hidrográficas dos mananciais no Estado de São Paulo. A lei apresenta as formas de intervenção na região em torno dos mananciais, dispondo quanto as áreas de restrição à ocupação, bem como a necessidade de implantação de infraestrutura com o fim de se minimizar os efeitos da ocupação já existente. 
Em decorrência da Lei Estadual no 9.866/1997 (São Paulo, 1997b) foram elaboradas diversas leis específicas para cada manancial, tratando de suas áreas de proteção e recuperação. Quanto ao manancial do Guarapiranga, foi apresentada a Lei Estadual n 12.233/2006 (São Paulo, 2006), a qual, como já citado, fixou as formas de ocupação do entorno da represa. Para regulamentar o disposto nesta lei, foi assinado o Decreto Estadual n ${ }^{0}$ 51.686/2007 (São Paulo, 2007), sendo que dentre as providencias deste decreto houve a delimitação específica quanto a ocupação e o uso do solo, bem como a extensão de uma faixa de 50 metros de largura em torno do reservatório com uma restrição a ocupação. Ressalva-se ainda que neste decreto ficou estabelecida a competência da Secretaria do Meio Ambiente para delimitar uma faixa de Preservação Permanente na margem do reservatório.

Em relação a legislação federal, que na seara ambiental possui uma maior relevância, podemos destacar, além da legislação apontada no Art. 194 do Plano Diretor Estratégico do Município de São Paulo (São Paulo, 2014), a Lei Federal no 12.651/2012 (Brasil, 2012), que revogou o Novo Código Florestal (Brasil, 1965), bem como a Resolução CONAMA nº 302/2002 (Brasil, 2002).

A Lei Federal $n^{\circ} 12.651 / 2012$ (Brasil, 2012) apresenta todo o aparato legal no que tange as normas gerais de proteção vegetal e áreas de preservação permanente. Já a Resolução CONAMA nº 302/2002 (Brasil, 2002) dispõe sobre os parâmetros, definições e limites de Áreas de Preservação Permanente de reservatórios artificiais e o regime de uso do entorno, possuindo assim grande influência sobre a legislação estadual e municipal quanto a estas regiões.

\subsection{DA APRESENTAÇÃO DA REPRESA EM SEUS ASPECTOS ATUAIS E DAS MEDIDAS JÁ TOMADAS}

O Relatório Final do projeto denominado Atualização do Plano de Desenvolvimento e Proteção Ambiental da Bacia Hidrográfica do Guarapiranga elaborado em 2006, pela Companhia Brasileira de Projetos e Empreendimentos em conjunto com a Coordenadoria de Planejamento Ambiental Estratégico e Educação Ambiental da Secretaria do Meio Ambiente, descreve a situação do Reservatório Guarapiranga.

"A bacia do reservatório abriga uma região de transição entre a mancha urbana da metrópole e as escarpas da Serra do Mar, ainda recobertas de remanescentes da Mata Atlântica. Incorpora, ao norte, territórios densamente urbanizados, concentrados, principalmente, em torno do lago; e, ao sul, territórios ainda relativamente preservados, compreendendo as cabeceiras dos rios Embu Guaçu e Santa Rita (seu afluente), já próximos à vertente marítima da Serra do Mar. A leste confronta-se com a bacia do Reservatório Billings, também bastante urbanizada no trecho próximo à barragem, e a sudeste, com a bacia do Capivari-Monos, ainda pouco ocupada. A oeste, confronta-se com a bacia do rio Cotia." (São Paulo, 2016b).

Neste mesmo relatório é apontado que a ocupação urbana é essencialmente caracterizada pelo uso habitacional e do setor de serviços, observando também a presença de indústrias na região. Quanto a este aspecto temos a porção norte da bacia, mais correspondente a área do reservatório, que apresenta uma rede urbana compactada que pressiona o território, avançando na forma de loteamentos pouco estruturados e, em geral, com altas densidades de ocupação do solo, chegando a densidade populacional desta região a valores de mais de 100 habitantes por hectare. Vale ressaltar que essa massa populacional ocasiona pressão para expansão da malha urbana em direção sul, acompanhando as principais vias da região, observando-se, porém, que tal pressão é feita tanto por população de baixa renda, bem como por população de renda mais elevada buscando uma melhor qualidade de vida. Tais assertivas são observadas na Figura a seguir. 


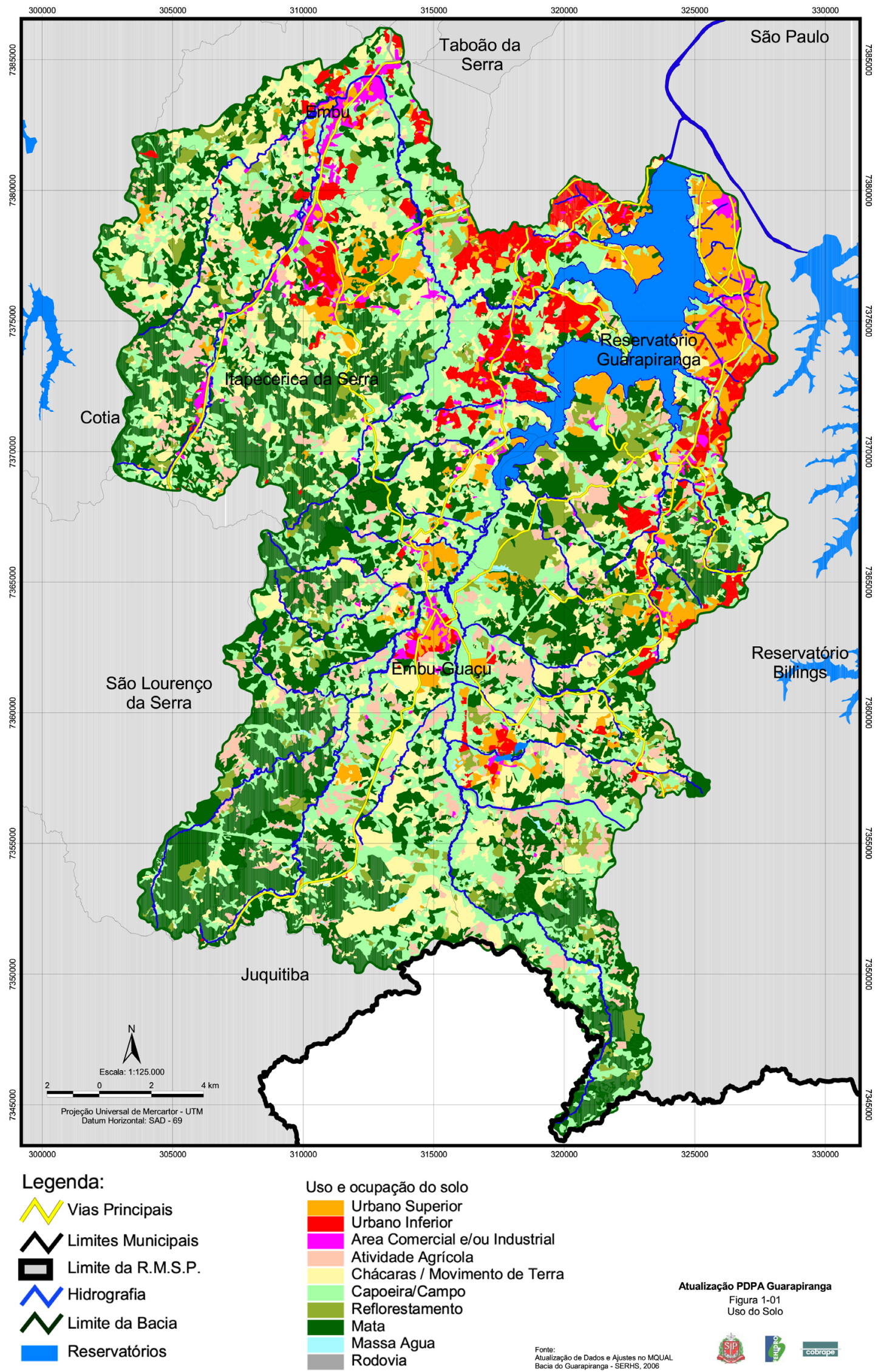

Figura 1. Ocupação do solo na Bacia Hidrográfica do Guarapiranga (São Paulo, 2016b). 
A Figura 1 apresenta a ocupação do solo na Bacia Hidrográfica do Guarapiranga (São Paulo, 2016b) e aponta uma forte ocupação tanto com moradias de alto e médio padrão, com a existência de equipamentos públicos e infraestrutura urbana instalada (área urbana de padrão superior/laranja), quanto com moradias de baixo padrão, amparados com alguns equipamentos públicos, mas com uma infraestrutura urbana deficitária (área urbana de padrão inferior/vermelho) (São Paulo, 2016b).

Assim, podemos observar um avanço por parte dos entes públicos ao reconhecer a existência de um problema quanto ao uso do solo nas regiões próximas ao manancial, com esse reconhecimento refletido no Plano Diretor Estratégico do Município de São Paulo (São Paulo, 2014) e na legislação estadual, em especial na Lei Estadual $n^{0}$ 11.216/2002 (São Paulo, 2002) e na Lei Estadual $n^{0}$ 12.233/2006 (São Paulo, 2006). Vislumbra-se, no entanto, o interesse destes em manter as ocupações nas regiões que não apresentam riscos à população que lá vive, tentando minimizar os danos ambientais com a implementação de infraestrutura básica.

Por sua vez, no que tange a infraestrutura de lazer, é possível observar um avanço por parte da municipalidade no sentido de transformar as margens do reservatório em espaços de lazer para a população da região.

Neste sentido temos a criação e revitalização de diversos parques que costeiam o reservatório, como os parques Guarapiranga, Praia São Paulo, Barragem de Guarapiranga, Linear Castelo, Linear Nove de Julho e Linear São José, sendo que estes últimos fazem parte de um programa denominado Operação Defesa das Águas, da Prefeitura de São Paulo e do Governo do Estado de São Paulo, o qual é voltado para controlar, recuperar e urbanizar de modo ordenado os mananciais, as matas, córregos e nascentes no Município de São Paulo (São Paulo, 1989b).

Observa-se ainda o Programa de revitalização da orla da Represa Guarapiranga (São Paulo, 2010) da Prefeitura de São Paulo, o qual prevê a implantação de instrumentos de forma a recuperar e integrar as margens da represa ao cotidiano das pessoas da população próxima, observando ainda o conceito de preservação ambiental para a implementação de equipamentos na orla. Neste programa ainda existe o trabalho da prefeitura em retomar áreas de sua propriedade e promover a aquisição de terrenos próximos a represa visando a ampliação dos parques implantados pelo programa Operação de Defesa das Águas, expandindo assim os equipamentos de lazer e de proteção ao meio ambiente.

Ressalta-se, porém, que referidas atuações dos entes públicos estão restritas a orla do manancial. No que tange às ocupações um pouco mais distantes, mesmo estas sendo importantes para manutenção sustentável do referido manancial, pouco se tem feito.

\section{CONCLUSÃO}

A partir do aspecto histórico, pode-se observar que a construção da Represa Guarapiranga representou um grande polo de atração à ocupação humana na região sul do Município de São Paulo. Em seus primórdios foi utilizada, de forma principal, para controlar a vazão da bacia hidrográfica do rio Tietê e, de forma secundária, como espaço para lazer. Com o crescimento da cidade, os bairros próximos ao reservatório passaram a receber cada vez mais moradores.

Vislumbrando tal crescimento os entes estaduais e municipais passaram a propor uma legislação mais restritiva quanto a ocupação das áreas, porém, o que se observou foi um efeito inverso, uma vez que a referida legislação ocasionou a queda do valor dos terrenos e, ante uma fiscalização ineficiente, houve um grande aumento na ocupação desordenada da região.

Em face de tal histórico encontrou-se em tempos atuais uma legislação que reconhece o problema da ocupação irregular, bem como da ocupação regular, mas com uma baixa infraestrutura tanto de saneamento como de equipamentos públicos, formando-se assim um conflito entre a garantia ao direito à moradia digna e ao direito à um meio ambiente ecologicamente equilibrado. 
Concluiu-se que a solução encontrada pelos legisladores foi a de manter os moradores no máximo dos casos possíveis, procedendo a transferências apenas nos casos de áreas consideradas de risco. Para os demais casos procede a Administração Pública a tentativa de minimizar os danos já causados, fornecendo assim a infraestrutura necessária (saneamento básico), bem como promovendo a instalação de equipamentos públicos na região, como parques, escolas entre outros, buscando garantir a função social da habitação em prejuízo de se promover uma recuperação ambiental.

Ressalta-se ainda que apesar de todos os mecanismos apresentados, tanto na Lei Estadual $\mathrm{n}^{\circ}$ 12.233/2006, quanto no Plano Diretor Estratégico do Município de São Paulo, a fiscalização é falha, aumentando cada vez mais a ocupação.

Aponta-se, porém, que mesmo com esse conflito, temos uma evolução no que tange ao direito a um meio ambiente ecologicamente equilibrado, bem como em relação ao direito ao lazer. Tal evolução deve-se à criação de diversos parques na orla da represa e de seus afluentes. Os referidos parques protegem tanto o meio ambiente quanto permitem a população da região acesso à equipamentos públicos para lazer, fator este importante em uma região carente das mesmas.

Por fim, pode-se concluir, que apesar de a legislação brasileira apresentar elementos de vanguarda quanto ao Direito Urbanístico, visando garantir as funções sociais da cidade, e apesar do que rege o Direito Ambiental, verifica-se que ainda é falha a aplicação desses conceitos, ainda que levando em consideração o fixado no Plano Diretor Estratégico do Município de São Paulo.

\section{AGRADECIMENTOS}

Agradecemos ao Dr. Luis Manuel Fonseca Pires, Juiz de Direito no Estado de São Paulo e Prof. de Direito Administrativo na Pontifícia Universidade Católica de São Paulo pela orientação e à Pesquisadora Científica Marilda Rapp de Eston pelo apoio dispensado.

\section{REFERÊNCIAS BIBLIOGRÁFICAS}

BRASIL. Decreto no 3.349, de 17 de julho de 1899. Concede autorização à The S.Paulo Railway Light and Power Company limited para funccionar na Republica dos Estados Unidos do Brazil. Disponível em: <http:// www.2.camara.leg.br/legin/fed/decret/1824-1899/decreto-3349-17-julho-1899-518144-publicacaooriginal-1pe.html>. Acesso em: 20 jun. 2016.

. Decreto-Lei $n^{\circ} 5.452$, de $1^{\circ}$ de maio de 1943. Aprova a Consolidação das Leis do Trabalho. Disponível em: <http://www.planalto.gov.br/ccivil_03/decreto-lei/Del5452.htm>. Acesso em: 21 jun. 2016.

Lei no 4.771 de 15 de setembro de 1965. Institui o novo Código Florestal. Disponível em: <http:// www.planalto.gov.br/ccivil_03/leis/L4771.htm>. Acesso em: 21 jun. 2016.

. Lei $n^{\circ}$ 6.938, de 31 de agosto de 1981. Dispõe sobre a Política Nacional de Meio Ambiente, seus fins e mecanismos de formulação e aplicação, e dá outras providências. Disponível em: <http://www.planalto.gov. br/ccivil_03/leis/L6938.htm>. Acesso em: 20 jun. 2016.

Constituição da República Federativa do Brasil de 1988. Disponível em: <http://www.planalto.gov.br/ ccivil_03/Constituicao/Constituicao.htm>. Acesso em: 21 jun. 2016.

Decreto $n^{\circ}$ 591, de 6 de julho de 1992a. Atos Internacionais, Pacto Internacional sobre Direitos

Econômicos, Sociais e Culturais. Promulgação. Disponível em: <http://www.planalto.gov.br/ccivil_03/ decreto/1990-1994/d0591.htm>. Acesso em: 20 jun. 2016. 
COELHO, A.R.E.P. Represa Guarapiranga: Direito à Moradia e a um Meio Ambiente Equilibrado.

BRASIL. Decreto no 592, de 6 de julho de 1992b. Atos Internacionais, Pacto Internacional sobre Direitos Civis e Políticos. Promulgação. Disponível em: <http://www.planalto.gov.br/ccivil_03/decreto/1990-1994/d0592. htm>. Acesso em: 20 jun. 2016.

. Emenda Constitucional n ${ }^{\circ} 26$, de 14 de fevereiro de 2000. Altera a redação do art. $6^{\circ}$ da Constituição Federal. Disponível em: <http://www.planalto.gov.br/ccivil_03/constituicao/emendas/emc/emc26.htm>. Acesso em: 20 jun. 2016.

. Lei $n^{\circ} 10.257$, de 10 de julho de 2001. Estatuto da Cidade. Regulamenta os arts. 182 e 183 da Constituição Federal, estabelece diretrizes gerais da política urbana e dá outras providências. Disponível em: $<\mathrm{http} / / \mathrm{www} 2$. camara.leg.br/atividade-legislativa/comissoes/comissoes-permanentes/cdu/part.html/estatutodacidade.pdf $>$. Acesso em: 20 jun. 2016.

. Resolução CONAMAn ${ }^{0}$ 302, de 20 de março de 2002. Dispõe sobre os parâmetros, definições e limites de Áreas de Preservação Permanente de reservatórios artificiais e o regime de uso do entorno. Disponível em: $<$ http://www.mma.gov.br/port/conama/legiabre.cfm?codlegi=298>. Acesso em: 21 jun. 2016.

Lei $\mathrm{n}^{\circ} 12.651$, de 25 de maio de 2012. Dispõe sobre a proteção da vegetação nativa; altera as Leis $\mathrm{n}^{\mathrm{o}}$ 6.938, de 31 de agosto de 1981, 9393, de 19 de dezembro de 1996, e 11.428, de 22 de dezembro de 2006; revoga as Leis $\mathrm{n}^{\mathrm{0}} 4.771$, de 15 de setembro de 1965, e 7.754, de 14 de abril de 1989, e a Medida Provisória ${ }^{\circ}$ 2.166-67, de 24 de agosto de 2001; e dá providências. Disponível em: <http://www.planalto.gov.br/ccivil_03/_ ato2011-2014/2012/lei/112651.htm>. Acesso em: 21 jun. 2016.

CARTA de Atenas. 1933. Disponível em: < http://portal.iphan.gov.br/uploads/ckfinder/arquivos/ Carta\%20 de\%20Atenas\%201933.pdf>. Acesso em: 21 jun. 2016.

COMPANHIA DE SANEAMENTO BÁSICO DO ESTADO DE SÃO PAULO - SABESP. Dossiê - Sistema Guarapiranga. 2008. Disponível em: <http://memoriasabesp.sabesp.com.br/acervos/dossies/pdf/9_sistema_ guarapiranga.pdf $>$. Acesso em: 21 jun. 2016.

COMPANHIA DE SANEAMENTO BÁSICO DO ESTADO DE SÃO PAULO - SABESP. Crise Hídrica, Estratégia e Soluções da SABESP - para a Região Metropolitana de São Paulo, 2015. Disponível em: $<$ http://site.sabesp.com.br/site/ uploads/file/crisehidrica/chess_crise_hidrica. pdf $>$. Acesso em: 30 abr. 2017.

DECLARAÇÃO de Estocolmo.1972. Declaração de Estocolmo sobre o ambiente humano. Publicada pela Conferência das Nações Unidas sobre o meio ambiente em junho de 1972. Disponível em: <www. direitoshumanos.usp.br/index.php/Meio-Ambiente/declaracao-de-estocolmo-sobre-o-ambiente-humano. html>. Acesso em: 20 jun. 2016.

DECLARAÇÃO do Rio de Janeiro.1992. Disponível em: <http://www.scielo.br/pdf/ea/ v6n15/v6n15a13. pdf $>$. Acesso em: 21 jun. 2016.

DI PIETRO, M. S. Z. Direito Administrativo. 26ª ed. São Paulo, SP: Atlas, 2013. 938 p.

FIORILlO, C. A. P. Curso de Direito Ambiental Brasileiro. 14ª ed. São Paulo, SP: Saraiva, 2013. 968 p.

MACHADO, P. A. L. Direito Ambiental Brasileiro. 24a ed. São Paulo, SP: Malheiros, 2016. 1407 p.

MELLO, C. A. B. de. Curso de Direito Administrativo. 32a ed. São Paulo, SP: Malheiros, 2015. 1150 p.

MILARÉ, É. Direito do Ambiente. 10ª ed. São Paulo, SP: Revista dos Tribunais, 2015. 1708 p.

PINTO, V. C. Direito Urbanístico - Plano Diretor e Direito de Propriedade. $4^{\mathrm{a}}$ ed. São Paulo, SP: Revista dos Tribunais, 2014. $336 \mathrm{p}$.

PIRES, L. M. F. Moradia e Propriedade: um breve ensaio sobre conflitos humanos. $1^{\text {a }}$ ed. Belo Horizonte: Fórum, 2015. $78 \mathrm{p}$. 
SÃO PAULO (Estado). Lei n ${ }^{\circ}$ 1.061-B, de 28 de dezembro de 1906. Concede à São Paulo Trainway Light and Power Company Limited, os favores da Lei 677, de 12 de setembro de 1899, para as obras de represamento das águas do Rio M'Boy-Guassu ou Guarapiranga. Disponível em: <http://www.al.sp.gov.br/repositorio/ legislacao/lei/1906/lei-1061B-28.12.1906.html>. Acesso em: 20 jun. 2016.

(Estado). Decreto $\mathrm{n}^{\circ} 4.487$, de 9 de novembro de 1928. Approva as clausulas para o contracto a ser celebrado com a “ The São Paulo Tramway, Light \& Power Company Limited” em execução da lei no 2.249, de 27 de dezembro de 1927. Disponível em:<http://www.al.sp.gov.br/repositorio/legislacao/decreto/1928/ decreto-4487-09.11.1928.html>. Acesso em: 20 jun. 2016.

(Estado). Lei n ${ }^{\circ} 898$, de 18 de dezembro de 1975. Disciplina o uso do solo para proteção dos mananciais, cursos e reservatórios de água e demais recursos hídricos de interesse da Região Metropolitana da Grande São Paulo. Disponível em: < http://www.al.sp.gov.br/norma/?id=44829>. Acesso em: 21 jun. 2016.

(Estado). Lei $\mathrm{n}^{\circ}$ 1.172, de 17 de novembro de 1976. Delimita as áreas de proteção relativas aos mananciais, cursos e reservatórios de água, a que se refere o Artigo 2. ${ }^{\circ}$ da Lei n. 898, de 18 de dezembro de 1975, estabelece normas de restrição de uso do solo em tais áreas e dá providências correlatas. Disponível em: $<$ http://www.al.sp.gov.br/norma/?id=29141>. Acesso em: 21 jun. 2016.

(Estado). Constituição Estadual, de 05 de outubro de 1989a. Disponível em: <http://www.al.sp.gov.br/ repositorio/legislacao/constituicao/1989/constituicao-0-05.10.1989. html>. Acesso em: 20 jun. 2016.

(Estado). Decreto $\mathrm{n}^{\circ}$ 30.442, de 20 de setembro de 1989b. Cria o Parque Ecológico do Guarapiranga. Disponível em: http://www.al.sp.gov.br/norma/?id=24346>. Acesso em: 21 jun. 2016.

(Estado). Lei Estadual no 9.509, de 20 de março de 1997a. Dispõe sobre a Política Estadual do Meio Ambiente, seus fins e mecanismos de formulação e aplicação. Disponível em:<http://www.pge.sp.gov.br/ centrodeestudos/bibliotecavirtual/dh/volume\%20i/amblei9509.htm>. Acesso em: 19 jun. 2016.

(Estado). Lei n ${ }^{\circ}$ 9.866, de 28 de novembro de 1997b. Dispõe sobre diretrizes e normas para a proteção e recuperação das bacias hidrográficas dos mananciais de interesse regional do Estado de São Paulo e dá outras providências. Disponível em: <http://www.al.sp.gov.br/norma/?id=5976>. Acesso em: 19 jun. 2016.

(Estado). Lei $\mathrm{n}^{\mathrm{o}}$ 11.216, de 22 de julho de 2002. Altera a Lei $\mathrm{n}^{\circ}$ 1.172, de 17 de novembro de 1976, que delimita as áreas de proteção dos mananciais, cursos e reservatórios de água de interesse da Região Metropolitana da Grande São Paulo. Disponível em: < http://www.al.sp.gov.br/norma/?id=193>. Acesso em: 20 jun. 2016.

(Estado). Decreto $n^{\circ}$ 47.696, de 07 de março de 2003. Regulamenta o artigo 37-A da Lei $n^{\circ} 1.172$, de 17 de novembro de 1976, acrescido pela Lei no 11.216, de 22 de julho de 2002, que delimita as áreas de proteção dos mananciais, cursos e reservatórios de água de interesse da Região Metropolitana da Grande São Paulo. Disponível em: <http://www.al.sp.gov.br/norma/?id=1720.>. Acesso em: 19 jun. 2016.

(Estado). Lein ${ }^{\circ} 12.233$, de 16 de janeiro de 2006. Define a Área de Proteção e Recuperação dos Mananciais da Bacia Hidrográfica do Guarapiranga. Disponível em: <http://www.al.sp.gov.br/norma/?id=59925>. Acesso em: 21 jun. 2016.

(Estado). Decreto $n^{\circ}$ 51.686, de 22 de março de 2007. Regulamenta dispositivos da Lei Estadual $n^{\circ}$ 12.233, de 16 de janeiro de 2006, - Lei Específica Guarapiranga, que define a Área de Proteção e Recuperação dos Mananciais da Bacia Hidrográfica do Guarapiranga - APRM-G. Disponível em: <http://www.al.sp.gov. br/norma/?id=71125>. Acesso em: 21 jun. 2016. 
COELHO, A.R.E.P. Represa Guarapiranga: Direito à Moradia e a um Meio Ambiente Equilibrado.

SÃO PAULO (Estado). Secretaria do Meio Ambiente/Coordenadoria de Educação Ambiental. Recursos Hídricos. São Paulo: SMA/CEA, 2011, 138 p. (Cadernos de Educação Ambiental, 14).

(Estado). Sistema Guarapiranga. 2016a. Disponível em: $<$ http://www.nivelaguasaopaulo.com/sistema/ guarapiranga $>$. Acesso em: 20 jun. 2016.

(Estado). Relatório Final - Atualização do Plano de Desenvolvimento e Proteção Ambiental (PDPA) da Bacia Hidrográfica do Guarapiranga. 2016b. Disponível em: <http://www.ambiente.sp.gov.br/cpla/2013/03/14/ aprm-area-de-protecao-e-recuperacao-de-mananciais/>. Acesso em: 21 jun. 2016.

(Município). Programa de revitalização da orla da represa Guarapiranga. Portal da Prefeitura da Cidade de São Paulo, São Paulo, 05 abr. 2010. Disponível em: <http://www.prefeitura.sp.gov.br/cidade/secretarias/ subprefeituras/capela_do_socorro/noticias/?p=9257>. Acesso em: 21 jun. 2016.

(Município). Lei $\mathrm{n}^{\mathrm{o}}$ 16.050, de 31 de julho de 2014. Aprova a Política de Desenvolvimento Urbano e o Plano Diretor Estratégico do Município de São Paulo e revoga a Lei no 13.430/2002. Disponível em: <http:// www.prefeitura.sp.gov.br/cidade/secretarias/upload/chamadas/2014-07-31_-_lei_16050_-_plano_diretor_ estrategico_1428507821.pdf>. Acesso em: 19 jun. 2016.

(Município). Lei $\mathrm{n}^{\circ}$ 16.402, de 22 de março de 2016. Disciplina o parcelamento, o uso e a ocupação do solo no Município de São Paulo, de acordo com a Lei $n^{\circ}$ 16.050, de 31 de julho de 2014 - Plano Diretor Estratégico (PDE). Disponível em: <http://documentacao.camara.sp.gov.br/iah/ fulltext/leis/L16402.pdf $>$. Acesso em: 02 jan. 2017.

SARLET, I. W.; MARINONI, L. G.; MITIDIERO, D. Curso de Direito Constitucional. $2^{\text {a }}$ ed. São Paulo, SP: Revista dos Tribunais, 2013. 1340 p.

SILVA, J. A. da. Direito Urbanístico Brasileiro. $7^{\text {a }}$ ed. São Paulo, SP: Malheiros, 2015. 471 p. 